\title{
The Possibility of Solidarity or Broken Relationship Between Social Relatives and Women Prisoners in Tunisia
}

\author{
Maissène BEN ARAB ${ }^{1 *}$, Ali ELLOUMI² \\ ${ }^{1}$ University of Sfax Tunisia, Faculty of Arts and Humanities, \\ LARIDIAME Laboratory, University of Sfax -Tunisia \\ 2TEC Laboratory, Paris Descartes University, France \\ LARIDIAME Laboratory, University of Sfax, Tunisia
}

\begin{abstract}
Confronted with a body of research conducted in different contexts, the results obtained in the present study showed great similarities. Inspired by the work that analyzed the plurality of family solidarity, a set of studies focusing on prison relationships focused on the commitment of relatives to the prisoner. These different works have sought to specify the different forms of solidarity that the family brings to the detainee. Family solidarity is manifested, in a functional dimension, through material assistance and visits. In an emotional dimension, it reflects the psychological support provided by the family to the detainee relative. Beyond the material support that the immediate family provides to the inmates, emotional assistance and emotional support remain very important to ease prison constraints. The emotional closeness of families is meant to be protective. Again, this issue is under-documented, making any confrontation of the results impossible. Without specifying the emotional support of the family, family solidarity is advanced as very strong support to the prisoner during incarceration but also after release. Indeed, the question of family solidarity in the face of incarceration aroused the interest of sociological research very early on. In addition, the need to preserve family-prisoner ties is currently considered an essential means of reintegration. For many researchers, maintaining family relationships during incarceration is a very important factor in the decline in the recidivism rate. The role of the family is now considered essential to maintaining prison balance. In a gendered dimension, the results obtained also reflect less family solidarity towards women prisoners.
\end{abstract}

Keywords: incarcerated; women prison; social relations; family relationship; Manouba prison for women

\section{INTRODUCTION}

This sociological research is based on the relational side of ex-prisoners with their families and the analysis of 17 semidirective interviews, conducted with women prisoners during their incarceration, on the type of relationships, they establish with their loved ones and family adjustments to the constraints of incarceration. This article explains the success or failure of continuing the family relationship with women offenders during their incarceration.

Apart from its reproductive function, the family has always been considered as a fundamental institution that provides functions of cohesion, stability, socialization, and solidarity (Alain Bouregba, 2002, p. 83).

As a source of social ties, family solidarity is considered both as social protection and insurance against economic hazards and social constraints (Jean-Hugues DECHAUX, 1990, p.99).

However, the incarceration of a relative certainly modifies these functions and questions the family's relational behavior with the detainee and the meaning that the latter gives to such a relationship.

Indeed, incarceration, as a singular ordeal experienced by an individual, seems to inevitably have repercussions on the relationship of the family to the prisoner.
Following incarceration, the prisoner and her relatives are temporarily separated and exchanged according to procedures set by the prison administration. This separation, therefore, puts family ties to the test. The importance of these links necessarily depends on the relational intensity of the different actors, their perceptions of female incarceration, and the different financial constraints that weigh on the family (Gwenola RICORDEAU, 2008, pp. 79-80).

The testimonies collected provide information on the importance of the family in difficult times. As a social organization, the family seems to play a key role when a family member is incarcerated.

The former detainees interviewed stressed the importance of the family body in all its aspects and circumstances. Even if it is unanimously accepted that the family is indispensable, it does not always seem to adopt an attitude of solidarity during difficult times. Indeed, in the face of the ordeal of incarceration, not all families are supportive and not all to the same degree. The ordeal of incarceration is one of the major challenges faced by both the inmate and her family. Families can continue to maintain links with the detained relative by providing assistance and support. Others may decide to break these ties. For reasons of financial difficulties and distance from the place of incarceration of the relative, the family-detainee relationship may be blocked. 
The study of incarceration-proof social ties offers a more heterogeneous and nuanced picture. A set of highly interwoven factors determines the family-inmate relationship. In doing so, to analyze the family-inmate relationship is to examine the degree of family solidarity before incarceration, the representation of the family for female incarceration, and the type of crime committed. The financial situation of the family and the location of the place of incarceration largely influence the family-inmate relationship. The review of the interviews made it possible to categorize two ideal-types representatives of this relationship. A relationship of solidarity, a broken relationship.

Thus, and as paradoxical as it may seem, the prison experience does not seem to automatically break the relationship with the family but can even intensify it. Indeed, while many family ties are broken through the ordeal of incarceration, others are strengthened by great solidarity.

Several studies report that incarceration has helped strengthen family ties. Dominique Lhuilier reports that the ordeal of incarceration can strengthen the bonds between couples. The results of this research reveal two antagonistic situations. A relationship of solidarity and a broken relationship (Dominique LHUILIER, 2001, p. 167). Moreover, the preservation of family-detainee links is considered a determining factor in the social reintegration of the detainee after his release (Bernard CHANOUAT, 2011, p.80).

\section{METHODOLOGY AND MATERIALS}

This research aims to understand prison social relations at the manouba prison for women in the province of Tunis. Access to this object is part of a perspective of the subjective experience of these. In addition, potential prison relationships will be captured through the particular and unique experiences of each inmate.

Obviously, the methodological choice was made on the basis of the objectives previously set and the theoretical considerations advocated.

The first step was carried out by intending to describe and argue the relevance of the qualitative approach chosen to understand the subjective reality of the relationships established between women prisoners and the various social actors (guards, pairs, and close family). In the second step, the characteristics of the sampling procedure adopted for carrying out the survey are set out. In the third step, presented a topological analysis as a procedure for analyzing qualitative data. Finally, the difficulties encountered in carrying out this survey are explained. The qualitative approach allows, in addition to understanding the relational behaviors of people in a singular situation, to grasp the meaning that actors give to their reality from their points of view and the meaning they give to their situation.

As a research methodology, the qualitative approach integrates the subjectivity of the actors and the meaning they give to their experiences. The subjective nature of the prison experience gives it a private dimension that presupposes that access to it would only be possible through the words of the inmates and their point of view. In this sense and at the micro-social level, the qualitative investigation would be a shift in relation to the institutional point of view. In order to better understand the relational dynamics in the prison environment through the experience of women who have been incarcerated, the qualitative approach centered on thermalization seems very appropriate and essential. Applied to women's prison relationships, the qualitative methodology is conceived as a privileged instrument for capturing the social life of incarcerated women. It represents, in fact, a very suitable tool for the collection of information on prison relationships as they are experienced and reported by inmates. It will then be possible to shed light on littleknown grey areas of social life in prison. It also makes it possible to grasp the power of action of women considered as actors to weave prison social relations according to their prison reality and according to the various relative tactics put in place.

Thanks to its flexibility, qualitative research contributes to the deep and original exploration of phenomena as complex as incarceration. It is an analysis of experiences, that is to say, the ways of living the prison situation and the social relations inherent from the speeches of the exprisoners. In the case of this research, the qualitative method is based on the meeting of ex-prisoners in the manouba prison and should make it possible to grasp the prison experience of 17 women and the relative relational dynamics based on their words.

\section{RESULTS \\ Type of Relationships}

\section{Solider Relationship (Material/Emotional)}

\section{- Material Relationship}

Sociological studies are increasingly interested in "family solidarity". In its general acceptance, family solidarity refers to the relationships between members of a social group with a community of interests reflecting exchanges and support. As a source of social ties, protection against economic hazards, and support in the face of social contingencies, family solidarity tends to be considered both as social protection and as insurance. For Alain Bouregba, maintaining family ties would have a double objective: the preservation of public health and social cohesion. Adapted to the prison field, family solidarity refers to all the material and psychological help provided by families to detained relatives from arrest through incarceration to the post-prison period (Marion VACHERET, Mairie-Marthe COUSINEAU, 2005, p.381).

In the context of the present work, solidarity should be understood through the family visits and their frequency and through the material and emotional support provided by the detainee during the period of incarceration.

While family solidarity is in great demand by prisoners during the period of incarceration, it is also considered a determining factor in the social rehabilitation of the prisoner after his release.

This study will focus on the apprehension of the help provided by the family during the period of incarceration. Family solidarity over this period is all the more appreciable as the contribution of the prison institution to prisoners seems insufficient. Indeed, the goods and services provided in prison are far from covering the needs of prisoners. The failure of the Tunisian state seems to weigh heavily on the budget of the prison institution, which is experiencing great difficulties in guaranteeing conditions of detention in accordance with human dignity. In this context, potential family help appears to be a necessary complement to improve the daily prison life of prisoners. In many societies, mainly the Mediterranean, family solidarity with the detained relative can be part of what Edward Banfield should call "amoral familism". Solidarity appears as a moral necessity that reflects the strength connecting the members of the same family and the intensity of their cohesion (BANFIELD, 1958, p. 101). 
In a new reflection on detention, the family would play a key role in the reintegration of the detainee and his socialization and should therefore be reconsidered in the actions undertaken in the rehabilitation program of offenders. By specifying gender, family solidarity seems to take a different turn and is part of social logic that cultivates differentiation between the sexes and consolidates the unequal treatment that favors men over women. This cultural product obeys the idea of the primacy of man over woman. Even in a situation of violation of norms or laws, families are tolerant of the masculine and intolerant of the feminine. The detention of a woman is socially filled with pejorative representations even at the family level. This social construct, well internalized in Tunisian society, guides, according to the words of the women interviewed the behavior of the family during the incarceration of a loved one. Family solidarity would be stronger towards the masculine than the feminine.

... with my brother it was not the same... my brother went to jail... my father sometimes with my mother left to visit him... Mom spent two days preparing her favorite dishes for her... my father kept asking her if she wanted him to bring something else back... I also participated in the preparation of the couffin... it was my brother... whatever he did.. he remains my brother... my parents were looking forward to the day of the visit... it is their son. (Ons, age at incarceration: 43 years, 2 years in prison)

Although nuanced, family solidarity with women prisoners remains pervasive.

... my parents know me well... they were always by my side....my big brother came often... as soon as he could....(Yousra, age at incarceration: 19. 6 months in prison)

Almost all interviewees equate the family with the mother. When discussing the family relationship, almost all of the women who participated in the study talked about the merit of their mothers. In accordance with the hegemonic social construction of the protective and altruistic "good mother" in Tunisian society, mothers would seem to maintain the assistant and unconditional relationship with their daughters during the difficult period of incarceration.

... it was my mother (lamima) who came every week... may she forgive me (inchallah tsamahni)... may God preserve my mother (lamima la yaktaha)... if she leaves... there will be nothing left... (Sonia, age at incarceration: 27 years, 8 months in prison).

The mother's solidarity does not seem to disappear despite the disagreement or anger towards the detained daughter. Reproaches go hand in hand with solidarity and mutual aid. This behavior, as paradoxical as it may seem, highlights the protective role of the mother.

...I hope she forgives me (nchallah tsamahni)... the mother has no equal... despite everything I did.. she didn't let me down....she was angry with me... but she continued to help me.. no one can replace the mother... rabi ykhaliha.. (Fadwa, age at incarceration: 31 years, 6 months in prison)

Once again, in the speeches of some of the women interviewed, the resistance of traditional models of gender difference arises. In the social construct, fathers are less concerned with the function of solidarity. Fathers do not usually get involved with their incarcerated daughters. A very marked opposition appears between the attitude of mothers and that of fathers in the face of the ordeal of incarceration of their daughter.

... my father I have never seen him since my incarceration... he made no effort... he never helped my mother... she endured my incarceration alone... he didn't care much... (Sonia, age at incarceration: 27 years, 8 months in prison).

If the solidarity of the mother is unconditional, that of the father or brothers is conditioned by the nature of the prisoner's relationship with her family in a pre-prison period. The degree of trust between the inmate and her family is a very important ingredient of family solidarity. Although polysemic, the concept of trust can be articulated around the nature of the education provided by parents to their daughter, the different values transmitted and the parents' conviction of the non-gravity of the crime committed or evens the innocence of their daughter. The maintenance of family-inmate relationships during incarceration is in fact only the continuation of the strong relationship that united them before.

... my parents know me well... they were always by my side... they knew I was there by mistake... a small incident.. they come every week. ....I had neither stolen ... nor killed... my big brother came often.. as soon as he could... he reassured me... did you believe that if I was guilty or I committed a crime.. my parents would have been by my side... never... my parents my well educated.... (Yousra, age at incarceration: 19 years, 6 months in prison).

The solidarity of other family members, apart from parents, is very infrequent. Few interlocutors spoke of sibling visits.

... it was my sister who came. All the time... my sister I saw her every week... I was looking forward to that day.... I and my sister loved one a lot... we also got along... (Sawssen, age at incarceration: 26 years, 5 months in prison)

In referring to the relationship between the inmate and her family, it seems very legitimate to question the degree of resistance of the couple's ties to the ordeal of the woman's incarceration. If reciprocal solidarity is an obligation in the commitment of couples, it seems to be maintained only rarely when the woman is incarcerated. The husband's solidarity was only very rarely mentioned in the participants' speeches.

...Yes I had regular visits... my husband always came... and my family too... my parents came despite their advanced age... my brothers too... I love them all... (Chaima, age at incarceration: 35 years, 12 months in prison).

As a rule, the incarceration of the woman results in an interruption of the conjugal relationship. This situation involves new challenges for family members. Indeed, the distress caused by the detention of the mother and the disengagement of the father can only have a negative impact on the structure of the family and disturb the stability of the children. This trend has been reinforced by the results of a good number of field studies. In support of research on prisons in Bolivia, Alison Louise Speeding establishes a causal and automatic relationship between the incarceration of a woman and the destruction of the couple but also a dissociation of the family (Alisson Louise SPEDDING, 1999, p. 14)

... my husband is completely disengaged ... when I was in prison... he came for a visit to tell me that he was going to 
take my son to my mother's house... for he could not take care of it... I supported him a lot ... I suffered a lot... I was working to help him... the first time.. he abandoned us... me and his son... you can never trust a man... they are all the same... they are only looking for their tranquility...I was too upset (takhart ala rouhi)... ... (Fadwa, age at incarceration: 31 years, 6 months in prison).

Stanley Brodsky, for his part, suggests that the woman who is being incarcerated by the spouse shows great solidarity with the spouse but also with her family. It tends to preserve the cohesion of the whole family. This attitude is very rare when the woman is incarcerated. In the latter case, children are usually placed, adopted, or live with relatives. The family is systematically destroyed (Stanley BRODSKY, 1975, pp103-104).

Women's solidarity can be explained by what Morris calls "the service syndrome" or even by the complementary nature of "the neurosis of the couple." Without confirming or denying these potential explanations, the wives of detainees usually invoke the husband's kindness to themselves and to the children and sentimental attachment. Solidarity on moral grounds is totally ignored. The social issues surrounding family solidarity with a detained relative cannot, without doubt, be interpreted as a lack of support. The family continues to be a very important vector of solidarity. Family solidarity, which is the ordeal of incarcerating a loved one, still persists despite its low frequency and manifests itself in different forms.

Conceptually, the notion of Family Solidarity to a close detained person seems to be easy to conceive. It refers to visits, material assistance and psychological support. Solidarity concerns the extended family or the family network, but it is also associated with the worlds of kinship and surroundings (Gérard De CONINCK, 1992, p.90).

Understood in terms of visits to prisoners, family solidarity tends to promote their social integration and considerably reduces the rate of recidivism. This relationship has been confirmed by the majority of sociological studies. Notably that of Jules Quentin Burtein. A negative and very significant relationship was established between the frequency of visits and the recidivism rate. With a view to maintaining family ties during the period of incarceration, ex-inmates interviewed as part of this research reported that visits were generally regular. Speaking of her parents' solidarity, an interlocutor venerates the regular visits they made to her (Jules Quentin BURTEIN, 1977, pp.123-128).

....they came every week to see me...... (Yousra, age at incarceration: 19, years, 6 months in prison)

The majority of visits made by mothers are generally regular.

.. it was my mother (lamima) who came every week to forgive me (inchallah tsamahni). ... (Sonia, age at incarceration: 27 years, 8 months in prison).

For mothers, visits by incarcerated daughters are a mandatory and sacred weekly practice that continues and persists despite the deterrent conditions.

... it was my mother who came... not every week.. but she always came... sometimes when the weather was bad. when it rained.. I told myself that she wasn't going to come... but she came anyway... there is not like the heart of a mother... she always came...... (Fadwa, age at incarceration: 31 years, 6 months in prison).
Visits to detainees are certainly a very popular form of solidarity, but material solidarity is no less important in a context of detention characterized by great deprivation. Material solidarity is not without a heavy burden on the family budget. Indeed, the experience of detention seems to cause material, psychological and social costs for the inmates, but also for the immediate family. For Anne-Marie Marchetti, the lack of lucrative work for the inmate in prison means that most of the latter's resources come from families (Anne Marie MARCHETTI, 1997, p.66).

First of all, we distinguish the material support provided by the family to ensure the defense, carry out administrative procedures, and prepare the release of the detainee. This support is all the more restrictive as the financial resources of the families are limited.

... from the beginning they helped me....they paid a lawyer to defend me... it wasn't easy.. a lawyer is expensive.. my parents were not rich. alhamdoulillah sheltered from the need mastourin .. but the lawyer's charges overwhelmed them...... (Yousra, age at incarceration: 19 years, 6 months in prison).

Another financial burden on the families comes from the cost of visiting detainees. This cost includes the cost of transportation, monetary donation to the inmate, and inkind donations.

Travel incurs costs. The results of the survey Pierre Le Quéau estimate the cost of a visit at more than 28 euros on average. This sum does not seem to weigh heavily on the family budget. However, when this amount is renewed during each visit and when visits are frequent, the cost of the visit becomes significant. The cost of transportation is all the higher the greater the distance between the prison and the family's place of residence. Pierre Le Quéau estimates that for $20 \%$ of families, the cost of transport can reach 152 euros. Travel time to places of detention is also a significant cost. The geographical remoteness and the financial costs it entails are likely to hinder the maintenance of relations between the detainee and his relatives (Géraldine BOUCHARD, 2008, p.5) Some women interviewed said that the non-regularity of their mothers' visits is mainly due to the remoteness of the centers where they were placed and the lack of financial means (Pierre LE QUEAU, 2000, p. 50).

... my family didn't come often... it's very far away... my mother came from time to time... it's very far for her... transportation is expensive.. our house is in Sejnane... and she looked after my two children... she was the one who took care of them... she came about once a month. She brought me the couffin... clean linen...... (Yasmine, age at incarceration: 27 years, 4 months in prison).

The remoteness of the place of incarceration and the state of health of the mother constitutes a real blockage for the regularity of visits.

... my mother came once a month. my mother is old... she couldn't move around easily... she had to go more than 150 kilometers to come... every time she came...she asked me for forgiveness because she didn't come to all the visits. each time she explains herself .... talks about his fatigue and his state of health... I didn't blame him... I know she loved me (Lilia, age at incarceration: 36 years, 9 months in prison).

It seemed to me very illustrating to evoke the grief felt by the family when, for lack of means, did not provide for the needs of the detained relative. In this case, the comfort that the inmate brings to her family, despite her incarceration, is worth mentioning. 
.. my family never came... it's very far for them... and I did not receive mandates to make my purchases ... they didn't even have anything to eat... my mother worked in the fields (swani)... picking vegetables... my father is disabled... my parents were very poor... when I was outside it was me who provided for their needs... once my mother sent with the mother of a prisoner a cot ... and I learned that my mother was so sad because she couldn't help me anymore... I had a lot of grief... I let him know... through the prisoner and her mother that I was fine and that she does not send me anything anymore... (Najwa, age at incarceration: 32 years, 9 months in prison).

The monetary windfall provided, for the acquisition of vouchers, is another form of solidarity, costly in absolute terms but also in terms of share in the family budget. This cash transfer is increased by donations in kind (food, clothing,...).

According to the above-mentioned survey, $85 \%$ of detainees receive cash transfers from their families. However, a contrast was noted by the investigation concerning the amount of this financial windfall. While 17 $\%$ of detainees receive less than 77 euros per month from their families, 38\% receive between 77 euros and 152 euros and for $30 \%$ this sum is more than 152 euros. These cash transfers, made in the form of warrants, seem essential to live in prison. They can be used to rent a television, buy tobacco and toiletries.

According to Caroline Touraut, the mandates are very heavy costs that weigh on the family budget but which are necessary to ensure a minimum of comfort for the detainee and maintain solidarity and family help in the ordeal of detention. In the absence of any information on the monetary payments of Tunisian families to detained relatives, reference will be made only to the various lessons learned from the interviews carried out as part of this research to approach the issue of transfers to detainees (Caroline Touraut, 2012, p.89).

Capped in Tunisia at 100 dinars, the cash transfer made by the families of the inmates is converted to the penitentiary institution in the form of vouchers issued to their recipients. Most recently, in November 2020, the Tunisian Post Office made available to the families of detainees a network of offices at its headquarters to facilitate payments to detained relatives without moving to the penitentiary institution. This transferred financial windfall is not systematic and depends on a set of interlocking factors. Thus, first of all, the family must maintain links with the inmate. Then the family must be able to constitute the amount to be transferred. In addition, the financial situation of the detainee's family is very decisive in the transfer decision and the amount to be paid. When the family's financial situation is precarious, the material support provided to the detainee accentuates the poverty of the latter (Aubusson de Cavarlay , 1985, pp. 232-234).

... the payments of the mandates were regular... I was given 100 dinars every month... never less... my family didn't leave me.. hamdoulillah... ... (Chaima, age at incarceration: 35 years, 12 months in prison)

When the financial conditions of the family are severe, the payments made are likely to be significantly reduced until they reach the lower limit, which corresponds to a nonpayment.

.. when she had money.. she made payments to me.. for vouchers ... sometimes it was 30 dinars.. sometimes 25 .. and often nothing.. but I know she didn't have... (Fadwa, age at incarceration: 31 years, 6 months in prison)
Regardless of the number of cash transfers made by the family, it is far from representing all transfers. A significant part of the transfers is made in kind. Transfers in kind are made on the occasion of the purchase of goods given to the inmates mainly in the form of food and linen. All expenses combined, Pierre Le Quéau, director of the study, reports that relatives spend, on average, 200 euros per month for the incarcerated person. This expenditure represents $27 \%$ of family income. The burden of material support on the detainee tends to compress the family's budget items. $20 \%$ of the families surveyed say that financial assistance to the detainee is at the expense of expenses for children and health and contributes to impoverishing families (LE QUEAU, 2000, p.54).

To provide material support to detainees, the poorest families can seek help from family members, friends, and social services. It is clear from the speech of the women interviewed that despite the precarious situation of the families, they maintain bonds of solidarity with the close prisoner. This solidarity is very evident by the visits and their frequencies and especially by the material support, the couffin that the family brings to the detainee.

.. my mother came to all the visits... she was preparing food for me... she was preparing a lot of things... brought me warm clothes for the winter... (Hadami, age at incarceration: 34 years, 12 months in prison)

Often, the meals brought back by the mother were prepared according to the inmate's preferences. This clearly reduces the mother's desire to please her detained daughter.

..She brought me homemade cakes... which I loved very much... dumplings ... poor my mother... may she forgive me... (nchallah tsamahni)... (Amal, age at incarceration: 45 years, 5 months in prison)

Beyond the forms of solidarity of the families to the aforementioned prisoners, that which can extend to the children of the prisoner. Indeed, the incarceration of a mother brings out the problem of the care of children. When children are not placed, it is usually the family of the prisoner who welcomes them, thus creating an extension of family solidarity.

.. it was my mother who kept my son... she should take care of my son... his clothes .. his eat and in addition the medicines... when he was sick it was she who managed to take him to the doctor and buy him medicine... I hope she forgives me (nchallah tsamahni)... the mother has no equal.. (Fadwa, age at incarceration: 31 years, 6 months in prison)

When family solidarity with an incarcerated person has been addressed in the sociological analysis it is in terms of material and financial assistance. Emotional support has been largely ignored. However, the psychological and emotional assistance of prisoners by their families plays a very important role in improving daily prison life and in the socialization of the prisoner after his release. These potential impacts are reminiscent of the issues involved in the emotional support of the family.

\section{- Emotional Relationship}

More than a means of providing for the prisoner, family solidarity is manifested, in another dimension, by the moral, emotional, and symbolic support through which the bond of trust with the outside world is maintained. The emotional and psychological support of the family is for the prisoner a comfort and an assurance that makes it possible to reduce the tensions and difficulties related to the daily prison. 
In general, participants interviewed whose family ties were maintained during incarceration agreed that the emotional support of the mother helped them to make the prison stay less painful.

... She said as she left that ... rabi yfaraj alik... and this sentence I was waiting for at each visit... it warmed my heart... it helped me to bear the sentence of prison... (Sonia, age at incarceration: 27 years, 8 months in prison)

The emotional support is essentially manifested in the words of the interviewees by the prayers of the parents and these were perceived by the inmates as a real reassurance and comfort.

.. my parents reassured me... and prayed for me... my parents kept telling me all the time that they would always be by my side... I was always reassured.. and it gave me the strength to move forward... (Yousra, age at incarceration: 19 years, 6 months in prison)

The family's encouragement to the detainee appears in the speeches as a very soothing irrevocable psychological support. By the encouragement of the family, the inmates are reassured to face the prison ordeal.

..my parents told me that as long as I had their blessing I had nothing to fear. .. (Chaima, age at incarceration: 35 years, 12 months in prison)

All ex-detainees, even those whose family visits were irregular, say that their mother's visit gave them confidence, strength, and hope. Family visits are, therefore, a source of appeasement.

.... I was very happy when it was my mother who came ... she never missed the (ugly) parties....when I saw my mother.. I kept my spirits up for days and days... she was the mother and father to me...... (Yasmine, age at incarceration: 27 years, 4 months in prison)

A feeling of guilt towards the families and particularly towards the mothers intensely marked the speeches of the interviewees. The latter acknowledge their responsibility for the crime committed and attribute the suffering of their mothers and her fatigue to their incarceration.

... because of me, my mother suffered a lot... if I hadn't made a mistake.. if I have not been incarcerated... she would not have suffered all this... the poor woman was torn between prison and taking care of my son... I made a mistake.. and everything fell on my mother's head... I hope she forgives me (nchallah tsamahni)... the mother has no equal... despite everything I did.. she didn't let me down....she was angry with me... but she continued to help me.. no one can replace the mother... rabi ykhaliha.. (Fadwa, age at incarceration: 31 years, 6 months in prison)

While the analyses provide us with information on the forms of family solidarity, they do not make it possible to explain, however, the different logics that underlie them. In fact, no rigorous studies have been carried out in this direction. Family solidarity with a detained relative seems self-evident and is part of the obvious. We can think that it is part of the general commitment of the Tunisian family and its sacrifice to loved ones. When the detained subject is the girl, the solidarity of the parents would only be the extension of the altruistic behavior of the latter and the desire to support their child in the face of the ordeal of incarceration. Although not compulsory, the support provided by the family adheres to the implicit pattern of the existence of a tacit contract established between the members of the same family and which requires a minimum of solidarity, especially during vulnerable periods.

....in difficult times you only find your family... it was my mother who supported me and helped me... no one forgives you. but your family does... because you are their daughter... I did not find .. when I was in prison as my mother.. may God preserve it for me... (Najia, age at incarceration: 34,12 months in prison)

However, family solidarity in the face of incarceration of a detained relative should not be hastily interpreted as systematic behavior. Not all families are supportive. The relationship of inmates to their families may be broken. The influence of cultural values and social representations that convey perceptions of women's incarceration is decisive.

\section{- Broken Relationship}

As the term "family solidarity" falsely implies, not all families are "solidary" when it comes to the imprisonment of one of their members. Families may be reluctant to contact the detained relative. Generally defined as a setaside, the breakdown of the family relationship with a detained relative refers to the physical separation but also the psychological distance from the family following the incarceration of a loved one. According to Gendron, the break with relatives is a singular experience that reinforces the prisoner's sense of isolation and loneliness and would compromise his socialization after release. According to Michelle Grossman such effects would be particularly more harmful in women (Michelle GROSSMAN, 1992, p. 410).

In a gendered dimension, the break with the family and the consequent isolation of women prisoners are much more intense than that of men who more often continue to receive moral and material support from their loved ones during incarceration. This paradox is part of the differentiated socialization that is incumbent on the functioning of a patriarchal society. The patriarchal system shapes a reality where the deviance of women is heavily punished and that of men is less so.

...prison is very hard... especially for a woman.. no one forgives you... god forgives... people never... even the closest ones... my parents never came... I have never had any visits... they are ashamed of me... with my brother it was not the same... my brother went to jail... my father sometimes with my mother left to visit him... Mom spent two days preparing her favorite dishes for her... my father asked her without the one if she wanted him to bring something else back... I also participated in the preparation of the couffin... it was my brother... whatever he did.. he remains my brother... my parents were looking forward to the day of the visit... it is their son.. at first I cried a lot... but with time I had gotten used to it... it looks like I wasn't their daughter....(Ons, age at incarceration: 43 years, 2 years in prison)

While the termination of the relationship with the detainee is usually a family decision, in many situations the decision to sever ties comes from the inmate himself and not from his family. From the perspective of adaptation and socialization to the prison, the prisoner may seek to distance himself from his family by substituting the links of the latter with those of other prisoners. This deliberate removal may be necessary for prison socialization. Often interpreted by the immediate family as a disinterest of the detainee in him, or hardening of the latter, this decision may reflect the prisoner's desire to protect his family from the climate of prisons and external judgments. 
This behavior is perfectly similar to that of some patients observed by Erving Goffman (Erving GOFFMAN, 1968, p. 201)

In this work, the focus is on the family's decision to break ties with the inmates. The interviews carried out do not imply any decision to break up by the detainee.

..my family... I have never seen them since I arrived in prison... ... no one came... my parents didn't want to see me anymore... (Fouzia, age at incarceration: 39 years, 8 years in prison)

According to several respondents, the family breakdown during the prison phase was in fact only an accentuation of the fragility of relationships before incarceration. The family trajectory of inmates is often complex and attests to the fragility of family ties before the prison ordeal. Interviewees of this figure report that they were left to fend for themselves before their incarceration.

...even before my incarceration, I did not see them often ... we didn't have good relations... my father drank all the time... my mother forced my sisters and me to go to work in houses. We did the cleaning... I started working when I was 8 years old... I suffered a lot.. the money was from my mother who came to collect it every month... she never tried to listen to me... I would never forgive him... I was in prison because of them... My father... My mother... Everybody... when I was on the street I learned to manage to survive... I didn't count on anyone... I only think of them when I see the other prisoners being visited by their families... the days of the visits... I have the ball (ghossa)... allah ghaleb is my that was my destiny(hadaka li kteb)... for material assistance ... I managed to have it from the inside.. I'm used to ... ... (Fatma, age at incarceration: 30 years, 10 years in prison)

According to the respondents, the breakup involves a very close family mainly the brothers and sisters and fathers. In evoking broken relationships with fathers, automatic opposition refers to the solidarity of the mother. The disintegration of relations with inmates is very present among fathers. Fathers generally do not want to maintain ties with their daughters in prison.

... my father I have never seen him since my incarceration....not even once... I know he's sick... but he made no effort... he never helped my mother... she endured my incarceration alone... he didn't care much... may God preserve my mother (lamima la yaktaha)... if she leaves... there will be nothing left... The mother is not like the father... The mother loves her children very much... she was sad... not like the father.. Men... all men are tough... they have a hard heart...my father.. he never came (Sonia, age at incarceration: 27 years, 8 months in prison)

Only one woman she met cited, with great hatred, the lack of solidarity of her mother during her incarceration. In fact, this rupture is part of an extension of abundant preexisting in a pre-prison phase.

....I lived on the street... my family there is none... my mother remarried... My father.. I don't know anything about him... I was with my grandmother... I have never received a visit... my mother refused to take me in when my grandmother died...she knew I was in prison... but she never came... I didn't give a damn... I didn't even know her... but I will never forgive him.. (Naima, age at incarceration: 40 years, 12 years in prison)
If the usual look at the sibling relationship is that of complicity and solidarity, incarceration tests such a relationship. The severance of family ties may also be the result of siblings. A good number of ex-inmates interviewed reported that siblings broke off their relationship with them while they were incarcerated.

... in prison I didn't see anyone... my parents died... I have two brothers... but they never came to see me... ... my father advised them to take care of me if anything should ever happen to him... thank god they died without seeing me there... in prison... after the parents... there is no one who can love you... help you... nor brothers ... nor uncles... my brothers could come... they didn't live far away.... (Hadami, age at incarceration: 51 years, 3 months in prison)

It seems legitimate to think that the sisters' solidarity persists in the ordeal of incarceration. Most studies agree that solidarity, essentially moral, is very strong between sisters. In this sense, Mélanie Mauthner points out that the relationships between sisters would be very intense during youth but would tend to disappear over time. Marriage, professional life, and other occupations would explain, according to the author, distancing. Contrary to what has just been claimed, it is claimed that the solidarity of the sisters in the Tunisian family would be maintained and strengthened continuously. However, the interviewees' discourse on this subject largely shakes the myth of intense solidarity and unconditional between the sisters. Most respondents testified to the breakdown of ties with the sisters during incarceration (Melanie MAUTHNER, 2002, pp. 113-117)

... I even tried to summon my sister... through our social worker... she talked to him... but she said that her husband forbade her to visit me or see me.....too bad... For me it was over... when I was outside I helped everyone. ... (Laila, age at incarceration: 42 years, 3 years in prison)

The results of the aforementioned CREDOC survey report that for $48 \%$ of prisoners, the breakup involves a very close family mainly brothers and sisters and fathers. Mothers and wives are rarely mentioned.

The theory of "care" largely explains the solidarity of women who tend to look after the well-being of loved ones and to care about their difficulties. The severance of ties between family and prisoner is widely invoked for couples where one is incarcerated. In England, 50\% of couples separate after one year of spouse detention. Pauline Morris points out that the breakup is not automatic during the first incarceration of the spouse. The rupture is a consequence of the succession of convictions. (Pauline MORRIS, 1982, p.90).

The study carried out in 2002 by INSEE on the family history of 1700 men detained in French prisons suggests that incarceration as an ordeal alone cannot explain the couple's separation. According to the study, conjugal relationships were already disturbed and weakened before incarceration. $40 \%$ of detainees have experienced at least one breakup before detention. Incarceration as an ordeal only precipitates the already very likely breakdown of superficial family ties. Moreover, incarceration and the severance of ties with the inmate would, according to Laura Fishman, improve the living conditions of many families when the inmate was violent (Laura FISHMAN, 1990, p. 204).

Bonnie Carlson and Neil Cervera go so far as to make the in-laws responsible for separating the spouses. 
The inmate's mother, essentially, may feel guilty or at best empower the woman for the incarceration of the spouse. Incarceration is an opportunity to break this relationship (Bonnie CARLSON \& Neil CERVERA, 1992, p. 75).

If most studies conclude that the marital relationship is weakened by the ordeal of incarceration of husbands, this weakening would be more intense when it is the wife who is incarcerated.

...my husband is completely disengaged (jbad rouhou) ... when I was in prison... he came for a visit to tell me that he was going to take my son back to my mother's house... for he could not take care of it... since then I've never seen him again... I supported him a lot ... I suffered a lot... I was working to help him... the first time.. he abandoned us.. me and his son... you can never trust a man... they are all the same... they are only looking for their tranquility....I was too upset (takhart ala rouhi)... (Fadwa, age at incarceration: 31 years, 6 months in prison)

The decision to break off relations with the detained relative is part of different logic for the families. For many families, going to prison is more than enough reason to sever ties with the Owned. Prison is inherently stigmatizing. Far from the crime committed, having a loved one in prison is a shame that legitimizes the breakup. In Tunisian society, a woman who is in prison is labeled as an unfrequented bad woman and who shames her family. In this case, the family could opt for a break in ties with the detained relative.

According to Goffman, the stigma tends to spread. To avoid "contagion" "we most often prefer to avoid having too close relationships with stigmatized individuals or suppress them when they already exist". Shame seems "devastating" for the family. It is in this very logic that the family break with the detained relative is generally inscribed (Erving GOFFMAN, 1975, p.44).

Pierre Le Quéau reports that 20\% of those surveyed feel this shame. This feeling is more felt by the inmate's parents $(24 \%)$ than by the spouse (18\%). A consistent and likely reaction to this feeling would be the breakup and obstinacy to any visit to the inmate. The feeling of shame can push families to change their place of residence to avoid stigmatization of those around them. In some speeches, potential delinquent practices are not always punishable by the rejection of the family, but incarceration is (Pierre LE QUEAU, 2000, p.68).

... I went to jail three times.. my father said.. "you shame us"... but he never said it when I went out every morning and I manage to bring the money back... they never asked me how I was doing... and now I shame them... my parents never tried to see me... (Laila, age at incarceration: 42 years, 3 years in prison)

For others, the type of crime and its duration are decisive. The breakdown of relationships may be attributable to the type of misdemeanor/crime committed. For some families, certain offenses/crimes such as infanticide or murder for example are absolutely unacceptable. The family may severely reproach but may also break off all contact with the detainee.

... I have never been forgiven... I know that what I have committed is serious... allah ghaleb... I took the gold of a relative... I flew... when she saw me I pushed her and she fell on her head... she is not dead. I didn't want to hurt him. (Ons, age at incarceration: 43 years, 2 years in prison)
The difficulty of maintaining family ties with detained relatives seems to be mainly explained by the shame that families feel at the incarceration of a loved one.

The incarceration of a woman is very stigmatizing in Tunisian society. The termination may also be due to the nature of the offense committed. Far from being interrupted, relations with detained relatives may be blocked because of the geographical location of penitentiary institutions and the costs of transport and visits.

Starting from the premise that prison is a restrictive social environment where inmates build relationships with the various actors, I have sought, throughout this chapter, to apprehend them and grasp their singularity in the prison of the manouba for women.

Three main areas were explored: custodial relationships, inmate-inmate relationships, and inmate-close family relationships.

Regarding the first axis, four types of relationships have been constructed: a normed relationship, an abusive relationship, a differentiated relationship, and a relationship exchange.

With respect to inmate-inmate relationships, the analysis of the data collected has led to the development of three standard ideals that trace the singularity of inmate-inmate relational experiences: a relationship of solidarity, a conflictual relationship, and a sexual relationship.

By questioning the inmate-family relationship two types of relationships arose: a relationship of solidarity and a broken relationship.

\section{DISCUSSION}

By questioning the inmate-family relationship two types of relationships arose: a relationship of solidarity and a broken relationship. The solidary relationship of the family to the inmate is made through visits, payments of mandates, and the contribution of the couffin.

When confronted with a body of research carried out in different contexts, the results obtained in the present study showed great similarities.

Inspired by work that has analyzed the plurality of family solidarity, a body of studies focusing on prison relationships have focused on the commitment of relatives to the detainee. These different works have sought to specify the different forms of solidarity that the family brings to the prisoner. Family solidarity manifests itself, in a functional dimension, through material help and visits. In an emotional dimension, it reflects the psychological support provided by the family to the close detainee. As reported by Combessie (1995), Family solidarity manifests itself, in a functional dimension, through material help and visits. In an emotional dimension, it reflects the psychological support provided by the family to the close detainee. The results of the investigation conducted by CREDOC (2000) for the case of France also confirm the family's solidarity with the detainee.

In a gender dimension, the results obtained also reflect a lower level of family solidarity towards women prisoners. Also, mothers appear to be much more in solidarity with their detained daughters than the other members of the family.

The results obtained on the family-inmate relationship confirm the hypothesis put forward. The family's relationship with a detained relative diminishes as a result of incarceration. In the rare cases of maintaining bonds of 
solidarity it is usually on the part of the mother. The solidarity of mothers is manifested by material and psychological support during visits, which are generally regular despite the precarious economic conditions in most cases. The mothers' visits seem to soften the inmate's prison stay. Nothing surprising. This result is confirmed by almost all the results of empirical research which conclude that the massive mobilization of women in the dynamics of solidarity is manifest.

Stanley Brodsky (1975) reports that in a situation where a man is incarcerated, women, wives or mothers, are very supportive. Conversely, incarcerated women are less supported by men. Gwénola Ricordeau (2007) suggests that mothers show more solidarity with their imprisoned children than fathers.

However, this solidarity is not automatic, the results of this study report that the relationship between the prisoner and her family can be blocked. this result appears in a set of studies. The results of a study carried out in 2013 at the Joux la Ville prison for women revealed that $50 \%$ of the women surveyed did not receive any visits or any help from their families. The study also reports that the length of incarceration is negatively linked to maintaining family ties (Huet GUENHAEL, 2013).

The remoteness of the place of incarceration and the relative financial constraint largely explain the rupture. In effect, if the family's financial situation is vulnerable, the incarceration of a loved one can result in additional burdens that the family is unable to bear and is therefore forced to block the relationship. Very often, the relationship between the family and the inmate is broken. The passage to prison appears, in the results of the analysis, as a very important factor that discredits the inmate and legitimizes her total rejection by the family. Synonymous with shame for the family, the incarceration of a loved one would undoubtedly create the stigma of the family. The nature of the offense/crime committed is also a wellrepresented factor in explaining the breakdown of the family-prisoner relationship. Murder and crimes against children are generally punishable by exclusion from the family sphere. The rejection of the inmate begins in prison and continues after release.

Without wishing to generalize the results, this research made it possible to take a look at the lives of women incarcerated in Tunisia in its relational dimension. Understanding prison social relations would be the first step in the establishment of a program for the reintegration of women prisoners. Researchers in Tunisia have totally ignored women behind the walls. Based on the literature consulted, no sociological research has focused on the incarceration of women. More than a simple sociological investigation, the various results obtained are very useful insofar as they make it possible to rethink the functioning and control of women's prisons in Tunisia and to define better-designed strategies to regulate the relationship of supervisory staff with female prisoners, improve conditions of detention and give more space to the family, essentially the mother, in the process of reintegration.

While the incarceration of women appears to be the last resort of the public authorities in Tunisia to manage offenses and if it is impossible, in the current situation, to resort to other methods of treatment of women in the context of a possible reform of the detention regime, shortterm actions are urgent.

First of all, it is a question of taking into account the specificities of women. Studies are unanimous on the psychological fragility of women during detention.
Appropriate medical care would be required. Also, and indicative title, sanitary napkins are not provided by the prison authority. Vulnerable inmates who cannot afford are humiliated. The next steps are to set up a set of instruments to monitor the functioning of prisons. I am thinking in particular of the strict control of the supervisors in the performance of their duties. Exceeding the rules should be severely punished. It is legitimate to think that relationships based on favoritism, discrimination and violence can only lead to anxiety among inmates and increase tensions and defeat any resocialization program.

Far from being a disciplinary object, research on women's prisons in Tunisia must be a political and social priority. Indeed, having been incarcerated, these women still continue to be part of the community. The effectiveness of their participation in the construction of the Tunisia of tomorrow depends, to a large extent, on the performance of prisons for their role of correction but also of helping the reintegration of all these women. I invested in the incarceration of women by apprehending their prison social relations and the different logics they imply. Much remains to be explored about the lives of women behind walls.

\section{CONCLUSION}

The investigation of the family-inmate relationship as part of this research revealed that incarceration tests such a relationship. The results reveal two antagonistic situations. A relationship of solidarity and a broken relationship. The solidarity relationship is manifested in the stories of the ex-detainees by three essential forms: the permanence of visits, material, and emotional support. In this sense, the family is perceived as a source of help, where all material, financial and emotional support is provided to the inmates. The results obtained on the question of the inmate-family relationship to the test of incarceration shed light on the importance of the material and emotional solidarity provided to prisoners around women, mainly mothers. Family solidarity with detained relatives is profoundly determined by the gender system and appears to be an indicator of inequalities.

The results obtained on the question of the inmate-family relationship to the test of incarceration shed light on the importance of the material and emotional solidarity provided to prisoners around women, mainly mothers. This solidarity is versatile and takes the form of material support: visits, mandates sent, and telephone or moral communications. In accordance with the hypothesis put forward on the family-detainee relationship, the solidarity of the Tunisian family with the detained relatives is not absent. More than half of the women interviewed were supported by their families, mostly by their mothers, during their incarceration. This result can be interpreted as persistence of solidarity in the Tunisian family during difficult times. The altruistic behavior of families, mainly mothers, reflects the commitment and sacrifice to support detained relatives.

However, solidarity with women prisoners is not systematic. Subjected to the ordeal of incarceration, relationships between inmates and their families can be broken. The results obtained show the rupture configuration. In situations of rupture, a distinction must be made between ties that are voluntarily severed and that reflect a rejection and abandonment of the detainee by her immediate family and ties blocked under duress from the high financial and social costs associated with maintaining solidarity. The inmate's relationship with her family is the last axis around which two ideals have been built: a relationship of solidarity and a broken relationship. Each of the elaborate ideal-type is part of a singular logic that 
has been grasped from the perspective of Dubet's sociology of experience. This articulation should make it possible to understand how the relationships of the inmates with the various actors are built in a dynamic relationship between the margin of maneuver of the inmates and the prison conditions that constrain them. (DUBET)

\section{REFERENCES}

[1] BANFIELD, E. (1958), The Moral Basis of a Backward Society, Free Press, New York, pages 188.

[2] BOUCHARD, G. 2008, Prisons et Transitions familiales Vers une sociologie des conditions de vie des familles de détenus, Université Bordeaux II Victor Segalen, pp.1-9.

[3] BOUREGBA, A. (2002), Les Liens familiaux à l'épreuve du pénal, ed. Érès, pages 142.

[4] BRODSKY, S. (1975), Families and friends of men in prison: the uncertain relationship, Lexington, Mass., Lexington Books, pages 137.

[5] BURTEIN, Jules Quentin. 1977, Conjugal Visits in Prison: Psychological and Social Consequences, Lexington Books, Toronto. 148 Pages.

[6] CARLSON, B. E., CERVERA, N. (1992), Inmates and their Wives : Incarceration and Family Life, Greenwood Press, l'Université du Michigan, pages 163.

[7] CHANOUA, B. (2011), Reconstructing your life after prison: what future after the sanction, Editions de l'Atelier, Paris, pages 310.

[8] DE CAVARLAY, B.A, 1985, "Hommes, Peines et Infractions: La légalité de l'Inégalité, L'Année Sociologique (1940/1948-), vol. 35, Presses Universitaires de France, pp. 275-309, http://www.jstor.org/stable/27889868.

[9] De Coninck, G. (1992), La famille du détenu : de la suspicion à l'idéalisation, Déviance et société, Vol. 6 $\mathrm{N}^{\circ} 1$, p. 83-103.

[10] DECHAUX, J.H. (1990), Des relations de parenté inédites ?, Esprit, n 163, pp.91-105.

[11] Goffman, E. (1968). Asiles: études sur la condition sociale des malades mentaux et autres reclus, Editions de Minuit, Paris, pages 451.
[12] GOFFMAN, E. (1975), Stigmante : les usages sociaux des handicaps, Les Editions de Minuit, pages 176.

[13] GOSSMAN, M.G.1992, Two Perspectives on Aboriginal Female Suicides in Custody, Canadian Journal of Criminology, vol.34, n³-4, pp. 403-416.

[14] GUENHAEL, H. (2013), Rapport d'information de la Délégation aux Droits des Femmes et à l'Egalité des Chances entre les Hommes et les Femmes sur le Projet de la loi pénitentiaire $\left(\mathrm{N}^{\circ}\right.$ 1506), Assemblée Nationale, $\mathrm{N}^{\circ} 3670$.

[15] LE QUEAU, P. 2000, L'autre peine : Enquête exploratoire sur les conditions de vie des familles de détenus, Cahier de Recherche $\mathrm{n}^{\circ} 147$, FeniXX réédition numérique (CREDOC), pages 148. ISBN : 2307-47214-2.

[16] LHUILLIER, D., LEMISZEWSKA, A. (2001), Le choc carcéral: survivre en prison, Bayard, pages 310.

[17] MARCHETTI, A.M. (1997), Pauvretés en prison, Ramonville Saint-Agne, Editions Erès, Collection Trajets, pages 222 .

[18] MAUTHNER Mélanie. (2002), Sistering : Power and Change in Female Relationships, Palgrave Macmillan UK, pages 228 .

[19] RICORDEAU, G. (2008). 3. Les liens par-delà les murs : Les détenus et leurs proches. Solidarités et sentiments à l'ombre des murs, sous la direction de Ricordeau Gwenola, Autrement, pages 270.

[20] SPEDDING, A. L. 1999, Dreams of Living : Life in the Feminine Penitentiary Centre, Miraflores, La Paz, Bolivia, Anthropology Today, Vol. 15, n², p. 11-17. https://doi.org/10.2307/2678263

[21] TOURAUT,C. 2013, Aux frontières des prisons : les familles de détenus, Cultures \& Conflits, (90), pp. 7794. https://doi.org/10.4000/conflits.18736.

[22] VACHERE, M., COUSINEAU, M. (2005), L'évaluation $\mathrm{du}$ risque de récidive au sein du système correctionnel canadien: regards sur les limites d'un système, Déviance et Société, 29(4), pp.379-397. DOI: 10.3917/ds.294.0379. 